\title{
How to Use ICTs to Provide Better Services to Citizens: Brazil's e-Procurement
}

The Organization for Economic Cooperation and Development's (OECD) within its 30 member countries as well as globally, is promoting new forms of public management, new approaches to service delivery and new technologies changing how the public sector operates. Important dimension are preserving the trust of citizens in government while also devolving the public sector, ensuring conformity with government objectives, controlling expenditures, and monitoring performance. OECD has organized global for a to provide opportunities for participating countries so share their reform experiences in government modernization and policies aimed at increasing public sector efficiencies. The most recent Global Forum on Governance was held in Rio de Janeiro, Brazil in October 2007.

One forum session focused on improving citizengovernment interface. It was stressed that "the great degree of interactivity offered by new ICT has the potential to expand the scope, depth, and quality of government interactions with citizens and other key stakeholders. ICTs can ease the life of citizens by allowing personalized access to information or services online on 24/7 through dedicated portals. ICT can also offer a number of tools to governments to include citizens' views and suggestions on policy issues, including for example, government online discussion forums. At the same time, such new online tools pose significant challenges to governments in terms of their technical, political and institutional implications. One of the challenges is ensuring wide access to these new tools for all citizens. Another challenge is to ensure that the results of online consultation procedures feed into the decision-making process."

This forum featured presentation on how to use ICTs to provide better services to citizens. The following are excerpts from a paper describing Brazil's experience with e-Procurement.

\author{
Electronic Procurement Allows for Inspection by \\ Society
}

By Rogério Santanna, Secretary of Logistics and Information Technology, Ministry of Planning, Budget and Management, Brazil

The Brazilian Federal Government's experience with electronic government reveals the extraordinary potential of ICTs, mainly based on the Internet, in contributing towards establishing a better relationship between the government and society. Initiatives in this area allow citizens to more easily act as agents and coparticipants in political decision-making, and demand that the government conduct this process with greater transparency and reciprocity. As well as implementing electronic services that facilitate the lives of citizens and reduce the Custo-Brasil (Cost-of-Brazil), expanding the level of communication between the government and the different social segments has also become important in government procurement processes. They are an essential tool for implementing most of the policies that directly serve the population, such as the purchase of medicine, school textbooks, construction of bridges, public hospitals and schools, just to name a few examples.

In Brazil, procurement occurs through public bidding processes (auctions) held by the government for purchasing materials or hiring services. These bidding processes allow any legally-constituted company to enter the process for selecting the company that will provide services or materials to the government. Public auctions are the Federal Government's primary means of procurement, and can be either electronic or in-person. The electronic auction is a type of bidding process conducted over the Internet as a reverseauction; the winner is the entity offering the lowest price. The in-person auction, though managed by an 
electronic system, requires the physical presence of representatives from companies interested in supplying to the government during the whole auction process. It is worth noting that the electronic auction is efficient in competitive markets, that is, non-oligopolies, and is geared towards procuring common goods and services - those whose specifications are widely-known in the market, such as fuels, school textbooks, computers, and office supplies. The Federal Government's catalog contains about 50,000 material items and 2.500 service items. The massive use of electronic purchases, especially electronic auctions, in the procurement of goods and services by the Federal Public Administration has been a very successful initiative in Brazil. This type of purchasing represents a substantial evolution in public contracting because it entails considerable gains in economy, transparency, competitiveness, and control of the process as a whole. It also provides equal opportunity for applying to government contracts, especially in the case of smaller companies. Simpler procedures and widespread notification and promotion have increased participation by companies in this segment of public bidding processes. The use of electronic auctions has shown that a reduction in the price of goods and services procured by the Government does not depend on suppliers' size and capability, but on a greater number of auction participants. The electronic auction is the most democratic modality, since one of its greatest advantages is reducing costs for participating companies. Since all procedures are conducted over the Internet, the company does not need to send its employees, which would have to be done in conventional modalities whose processes are still paper-based. This increases competitiveness and strengthens the social aspect of the government's purchasing power as a tool for local and regional development.

As well as making access to public auctions more democratic, the electronic auction also represents savings for the government. An increase in competitiveness results in an average of $20 \%$ to $30 \%$ decrease in the price of goods and services procured by the Federal Government. It also reduces administrative costs, since the process occurs entirely over the Internet and the only documentation that needs to be verified is the documentation from the auction winner. If the documentation does not fulfill the administration's requirements, the second-place winner's documentation will be analyzed, and so on. Due to the simpler nature of these procedures, the electronic auction is the Federal Government's most agile type of bidding process - it takes an average of 17 days, from the moment when the purchase is made official at a given institution's procurement department to the moment when the contract is signed. Other modalities may take up to 120 days, and in these cases the documentation from all participants must be verified before they can participate in the public auction.

One of the main benefits to society, aside from cost reduction and greater agility, is the dematerialization of all these processes, rendering the procurement process much faster and transparent. All of the stages of the bidding process in this modality are made available to citizens and can be monitored in real time and accessed through "Free Access" at the www.comprasnet.gov.br website. This is the Brazilian Federal Government's procurement portal, where one can monitor ongoing auctions, closed and scheduled auctions, as well as procedures pertaining to electronic auctions, bids placed, winning bids, auction notices, rules, downloads, among others. Electronic purchases, therefore, help fight corruption in the sense that all the data is made available digitally. As such, the fact that this data can be monitored and tracked much more easily brings numerous benefits in terms of transparency and auditing, as well as solutions to different distortions and problems.

Aware of the importance of the electronic auction, the Brazilian government has concentrated its efforts in disseminating and consolidating electronic auctions in the Federal Administration. This modality was instituted by the Brazilian Federal Government in 2000, but its use was optional until 2005, when Presidential Decree number 5540 made it mandatory in the procurement of goods and services by the Federal Government. That same year also saw the publication of Presidential Decree number 5504, making this modality mandatory, preferably in its electronic format, for states, municipalities, and nongovernmental organizations making use of public resources voluntarily allocated by the Federal Government3. As well as the efforts involved in ensuring adherence to the legislation, we also highlight the efforts involved in properly training public servants in the use of this electronic tool. In order to promote the use of the electronic auctions within government institutions across all Brazilian states, we have implemented a corporate education program conducted through videoconferencing and broadcast simultaneously to several capitals, providing training for multiple civil servants at a much lower cost when compared to in-person auctions. This includes over 6000 civil servants involved with hiring having received training in electronic auctions since 2005, through regular and virtual courses. In June, 2007, virtual training in elec- 
tronic auctions was given to civil servants in all three levels of government who work with procurement, at the Comprasnet Virtual School.

All of these measures have led to the consolidation of electronic auctions as the modality most used for procurement in 2006 by the Federal Government, resulting in savings of R $\$ 1.8$ billion - about $14 \%$ of the bid value. In 2006, the equivalent of Real (R\$) 11.1 billion was procured through electronic auctions $-57 \%$ of all goods and services acquired. In 2002, electronic auctions accounted for only $0.8 \%$ of all procurement expenditures. The number increased to $3.8 \%$ in 2003 , $5.8 \%$ in 2004 and $20.8 \%$ in 2005 . The electronic auction was also the system preferred by micro- and smallsized businesses when offering goods and services to the Federal Government in 2006. Out of the R\$ 2.2 billion spent in this segment, $\mathrm{R} \$ 822$ million was spent through this modality. There has been a substantial increase in use of the electronic auction by micro- and small-sized businesses, going from $\mathrm{R} \$ 464.4$ million in 2005 to the above mentioned, R\$ 822 million in 2006. In 2004, the figure was $\mathrm{R} \$ 108.4$ million.

Transfer of resources from the Federal Government to another government level, as financial assistance, cooperation, or help, which is not a result of a constitutional or legal requirement, or destined to the Unitary Health System (SUS).

According to these results, the cumulative growth of electronic auctions in 2006, when compared to 2002, was $17.92 \%$. As for the total number of procurement processes, 27,682 electronic auctions were held $64.9 \%$ of all auctions. In total, the Federal Government has procured $\mathrm{R} \$ 19.5$ billion in common goods and services in 2006, which includes auctions as well as other, less-frequent modalities. The most recent balance of Federal Government purchases shows that the use of this modality has increased even more in 2007. Between January and May of 2007, electronic auctions accounted for R\$ 3.4 billion spent in procurement $67.5 \%$ of all procured goods and services. This percentage represents a $10 \%$ growth compared to the previous year. Once again, the electronic auction resulted in a cost reduction for the government - $\mathrm{R} \$ 477.4$ million were saved in 2007, about $12 \%$ of the total. All in all, about R $\$ 5$ billion were invested in the procurement of public goods and services during that period.

\section{Comprasnet}

Comprasnet was a world pioneer, and the only system in Brazil acknowledged by the World Bank and by the Inter-American Development Bank as a secure system that can be used for procurement with resources from both of these financial institutions. According to a 2006 World Bank study in electronic procurement, Comprasnet achieved the maximum efficiency standards in indicators for evaluating transparency, in divulging the auctions as well as their results, and in using competitive bidding methods.

The study, which analyzed electronic auctions held in 2005 and in the first three months of 2006, also showed that the percentage of annulled Federal Government electronic auctions is only $0.89 \%$, well under the $5 \%$ threshold stipulated by the analysis. This shows that the task of compiling the rules and regulations for these auctions has been efficiently performed by federal servants working in public procurement, since auction cancellations are usually due to technical flaws in the rules and regulations.

The study coordinator, Alexandre Borges de Oliveira, considers the Brazilian electronic auction to be a reference for the procurement of standardized goods and services by the public administration. In his opinion, "Comprasnet's statistics show a significant reduction in the time necessary for concluding the auctions, while at the same time obtaining a high level of competitiveness in the realm of government contracts". Oliveira also states that the system can produce managerial data and information to be used in strategic decision-making and planning of future purchases. As a result of Comprasnet's performance, other countries are signing cooperation agreements with Brazil to start using Comprasnet. Such is the case of Peru, which last year modified the source code of the Brazilian Electronic Auction so that it could be used in the country. The objective was to adapt the Peruvian government's procurement system to the recommendations made by the World Bank in order to ensure greater transparency and managerial capacity in government acquisitions. In 2001, a delegation from Peru visited several different electronic procurement systems in Brazil, and Comprasnet was chosen for being most suitable to the country's needs. To stimulate other government levels to increase transparency and the overall quality of Brazilian public services, the Federal Government made Comprasnet also available to states and municipalities and facilitated the application process for all interested parties. Currently, over 340 municipal and state institutions, as well as Indirect Federal Administration institutions such as government-owned public companies, use the system for electronic procurement. Important cities and states like São Paulo are using Comprasnet for their electron- 
ic auctions. This system is mandatory only for Direct Federal Administration institutions composed of the President's Office, ministries, and agencies and institutions linked to ministries.

\section{Greater transparency}

It is the intention of the Brazilian government to extend the use of electronic tools in public auctions held on the state and municipal levels. In order to integrate procedures with new information technologies, in January of this year the government sent to National Congress a proposal for modifying the General Auction Law so as to modernize legislation created in 19934, back when all processes were still paper-based. One of these changes is the possibility of conducting all hiring processes electronically, since nowadays only the actual auction can occur over the Internet, as well as making the auction mandatory for states and municipalities as well. These and other modifications for making public procurement more agile, efficient and visible are awaiting evaluation by the Federal Senate and are part of the initiatives of the Economic Acceleration Program (PAC)5, implemented by President Luiz Inácio Lula da Silva in January 2007.

With these changes, the volume of purchases conducted electronically should increase even more in the country, improving the level of transparency of a sector which, in the Federal Government alone, spent almost $\mathrm{R} \$ 20$ billion in common goods and services in 2006. Out of that total, R\$ 11 billion refer to electronic purchases whose data is being audited and which has been made available to federal auditing agencies. Paperbased processes may lead to administrative favoring and fraud, since they must go through several different people from the beginning of the process to the moment when the winners are divulged. However, when procurement is done electronically, the government is better able to parse databases to find non-explicit business rules, locate cartels, unlawful consortiums or even common price-setting.

Law 8.666 of June 21, 1993, available at http://www. comprasnet.gov.br/legislacao/leis/lei8666.pdf.

PAC's goal is to increase the level of investment in the Brazilian economy, leading to the country's sustainable growth. PAC's initiatives and goals are organized as part of a comprehensive set of infrastructure investments, as well as incentive for and facilitation of private investments. It also includes better spending of public resources by containing current expenditure growth and perfecting public management, in regards to both the fiscal budget and welfare and Social Security budgets.

Therefore, magnetic storage allows for different types of information to be tracked down and for great volumes of information to be cross-analyzed in order for distortions to be found. This is essential because the government is investigated by society, as per the Participative Budget 6 experience implemented by the Workers' Party in the city of Porto Alegre, capital of the state of Rio Grande do Sul in the south of the country - social entities and segments may follow up on different construction projects as well as resource transfers to states and municipalities. The Internet contains information on all related administrative matters, such as amounts transferred, receiving institutions, and periods.

The Participative Budget was first created in 1989 in Porto Alegre, capital of the state of Rio Grande do Sul, and consists of a process through which the population can directly decide how resources will be used in terms of construction and services to be executed by the municipal administration. It begins with preparatory meetings, which is when City Hall reports the finances of the previous year and presents its Investments and Services Plan for the following year. SUS was created by the 1988 Federal Constitution so as to remedy the inequality that permeated the health assistance being given to the population at the time. It made the system accessible to any citizen, completely free of charge. The following are part of the Unitary Health System: health units and centers, public hospitals - including teaching hospitals - laboratories, hemo-centers (blood banks), as well as research institutions and foundations.

In order to facilitate monitoring, every ministry has a section in their web portal entitled Public Transparency Page, containing information on the financial execution of programs headed by each institution and department, such as expenses pertaining to purchases or procurement of goods and services. The Transparency Portal (www.portaldatransparencia.gov.br) has information on the use of public federal money by the government, as well as information on public federal resources transferred to states, municipalities, and the Federal District.

Moreover, we are also prioritizing the creation of procurement-specific portals to be used as an important managerial tool by public servants working in this area, as well as for investigation by society. A few examples are the Medicine Portal and the Information Technology Portal (TIC), whose links are also included in Comprasnet. The former has information on medication and 
hospital materials procured through resources from the Unitary Health System (SUS) and can be accessed by institutions on the federal, state, and municipal levels, as well as suppliers, and society as a whole. The latter contains specific legislation for acquiring information technology, as well as regulations for surveillance agencies, best practices and specifications for standardizing goods and services procurement in this area. In this portal, users can find, for example, reference specifications for microcomputers, in their basic, standard, and advanced versions, as well as reference specifications for notebooks in two versions: one prioritizing mobility, greater autonomy and weight, and the other prioritizing performance. However, just ensuring that information is available on the Internet is not enough. It is of prime importance that the language and architecture used in the webpages be accessible to citizens, regardless of their different levels of knowledge in any specific topic or any physical limitations. As such, technical jargon that keeps information from being effectively used must be kept to an absolute minimum. These portals must also address the issues of accessibility, in order to ensure access by persons with physical disabilities.

In order to contribute towards making electronic Government services accessible by all, the Ministry of Planning has created the Electronic Government Accessibility Model (e-MAG), which contains a series of technical recommendations for creating and adapting portals so that they will be accessible by users with hearing or visual disabilities - this has recently become mandatory in all of the Federal Government. e-MAG is currently in its version 2.0 and was consolidated in 2005, after public consultation. Internet accessibility includes alternative graphic and auditory content that is clear and understandable. Users must be able to browse the website regardless of any physical, motor, perceptual, cultural, or social disability.

Another initiative in this sense was the creation of the List of Government Affairs (LAG), a list of intuitive and simplified terms for programs, projects, and other initiatives included in Federal Government portals. The objective is to facilitate browsing and to ensure that citizens will be able to find information regardless of their knowledge of the formal structure of the government. The LAG lists different nomenclatures that can be attributed to the same project or initiative and favors a layman vocabulary when dealing with public services. It also favors an independent definition scheme, connected to 17 areas central to the Federal Government, which will remain valid even when agencies undergo structural changes.
It is important to point out that these standards were consolidated after extensive public consultation through the Internet, by means of the Brazilian Electronic Government portal (www.governoeletronico.gov. br). Participation by the civil society is necessary for finding the standards included in the Electronic Government Program, which is also the case for e-MAG standards, the Electronic Government Interoperation Standards (e-PING) among many other examples. Listening to society is an integral part of Electronic Government processes; unfortunately, this is not what happens in most cases, when the administration defines its priorities based on what it deemed essential for the population without even consulting it, especially in the realm of electronic Government.

The Brazilian Electronic Government Program works with changing the nature of the relationship between the government and citizens, companies, and even other government agencies and institutions in order to improve the quality of services rendered; to promote interaction with companies and industries; and to strengthen civil participation through access to information and to a more efficient administration. The Ministry of Planning, Budget, and Management, through its Logistics and Information Technology Secretariat (SLTI), is also the Executive Secretariat of the Brazilian Electronic Government Executive Committee and provides the technical and administrative support needed for the Committee's operation. The e-PING standards defines a set of minimum premises, policies, and technical specifications that regulate the use of communication and information technologies (TIC) in the Federal Government, also establishing the conditions for interaction with the different levels of government, as well as with society in general. This architecture allows for systems with different applications to generate and exchange information in real time.

In the Brazilian Federal Government, we have tried to invert this logic and to have citizens play the main role in the political process, in order to provide more and better services electronically and to better address demands. We believe that no country will be able to become effectively modernized if these very relevant issues are not considered when public policies are formulated and if its processes are not transparent. In this sense, electronic procurement is an indispensable tool for raising efficiency and modernizing public management. Not only does it lead to cheaper, faster, and more competitive procurement, but it also contributes towards fighting corruption and allows society to monitor how the government is investing public resources. 
Well-informed citizens are more likely to participate politically and to monitor government action; as such, new communication and information technologies pose new challenges to public managers in all areas to be- come more transparent; they require a new way of governing. This is the path taken by the Federal Government for public procurement in Brazil. 